\title{
Molecular and epidemiological analysis of penicillinase producing strains of Neisseria gonorrhoeae isolated in Canada 1976-84: evolution of new auxotypes and $B$ lactamase encoding plasmids
}

\author{
J R DILLON, M PAUZÉ, AND K-H YEUNG \\ From the Antimicrobials and Molecular Biology Division, Bureau of Microbiology, Laboratory Centre for Disease \\ Control, Ottawa, Canada
}

SUMMARY Though the number of penicillinase producing Neisseria gonorrhoeae (PPNG) strains isolated in Canada comprises under $1 \%$ of all gonococcal isolates, it continues to increase appreciably each year. Most strains are imported from areas of endemic infection with PPNG strains. Two local outbreaks in 1984, however, were notable for the number of patients infected and for the distinctive phenotypes of the strains. One outbreak was caused by a wild type strain, of serovar BACJK with a new 3.05 megadalton penicillinase encoding plasmid, whereas the other was caused by strains with the Asiat plasmid type, serovar $\mathrm{AE}$ and with a proline and ornithine requiring auxotype. Five plasmid patterns (Africa+, Africa-, Asia+, Asia-, and Toronto+) were observed among the PPNG strains. The association between plasmid content and specific auxotype (such as Asia plasmid with proline requiring auxotype or Africa plasmid with wild type auxotype) and inhibition by phenylalanine continues to be unexplained.

\section{Introduction}

Since the isolation of the first penicillinase producing Neisseria gonorrhoeae (PPNG) strains in $1976^{1-3}$ and their subsequent worldwide dissemination,,$^{4-5}$ various methods have been used to monitor the dispersal of specific PPNG strains between countries. Initially, PPNG strains were distinguished as Asian or African type based on the geographic area of the first outbreak of infection with them and on the distinctive characteristics of their plasmid content, auxotype, and susceptibility to antimicrobials. ${ }^{4-10}$ Asian type strains originated in Asia, generally South East Asia, carried a 4.5 megadalton penicillinase encoding plasmid with or without a 24.5 megadalton transfer plasmid, were typed auxanographically as being either proline requiring or wild type, and were resistant to antibiotics such as tetracycline. African type strains, on the other hand, carried a 3.2 megadalton penicillinase encoding plasmid, required ornithine, and were moderately resistant to antibiotics compared with non-PPNG

Address for reprints: Dr J R Dillon, Antimicrobials and Molecular Biology Division, Bureau of Microbiology, Laboratory Centre for Disease Control, Tunney's Pasture, Ottawa, Ontario K1A OL2, Canada

Accepted for publication 15 November 1985 strains. The extension of the range of hosts of the $24 \cdot 5$ megadalton transfer plasmid to include strains harbouring the "African" plasmid as well as the spread of African and Asian type plasmids into gonococcal strains with other auxotypes has been documented by several workers ${ }^{11-16}$. Furthermore, new $B$ lactamase encoding plasmids, as identified by molecular size, have been found in gonococcal isolates..$^{17-19}$ More recently, serological ${ }^{20-22}$ and restriction endonuclease analysis techniques ${ }^{23}$ have been used to refine the methods of tracking the global dissemination of PPNG strains.

In some areas of Africa, Asia, and Europe, PPNG strains are found in $5 \%$ to $50 \%$ of all gonococcal isolates. ${ }^{492-27}$ In many of these areas indigenous foci of infection have been established. In Canada and other countries the incidence of PPNG strains is well under $5 \%$, and most strains continue to be imported. $^{8202128}$ Identifying PPNG strains helps to document the spread of these strains between countries, identifies new varieties, and is useful in tracking indigenous outbreaks. The study published here highlights all of these aspects by analysing molecular and epidemiological data about PPNG strains isolated in Canada in 1976-84. 


\section{Patients, materials, and methods}

\section{STRAINS OF BACTERIA}

Penicillinase producing strains of $\mathrm{N}$ gonorrhoeae were submitted to this centre for biological and genetic identification from provincial public health laboratories and other laboratory centres throughout Canada. Duplicate strains from patients were excluded from the study unless reinfection could be proved based on genetic and clinical criteria. (We did not observe simultaneous infection with strains of differing auxotype or plasmid profiles.) Reference strains for tests of minimum inhibitory concentrations, plasmid content, and auxotype have been described previously. ${ }^{8} 2$

\section{EPIDEMIOLOGICAL AND CLINICAL DATA}

After biological and molecular identification of the strains, questionnaires about clinical and epidemiological data were posted to laboratory and epidemiological authorities in the appropriate provinces. These data were collated and analysed using computer programs developed within this division. In some cases only epidemiological and clinical data could be obtained for PPNG isolates. Thus, though 623 isolates have been described epidemiologically, only 501 were submitted to our laboratory for biological identification.

\section{CULTURE METHODS}

Using standard identification criteria we confirmed that cultures submitted were $N$ gonorrhoeae and that they were PPNG strains by screening for $\beta$ lactamase production using Nitrocefin (Glaxo, Greenford, Middlesex, England). Strains were stored and subcultured as described previously. ${ }^{829}$

TABLE I Provincial incidence of penicillinase producing Neisseria gonorrhoeae (PPNG) strains isolated in Canada 1976-84

\begin{tabular}{|c|c|c|c|c|c|c|}
\hline \multirow[b]{2}{*}{ Province } & \multicolumn{6}{|c|}{ Number of PPNG strains isolated in: } \\
\hline & $1976-80$ & 1981 & 1982 & 1983 & 1984 & Total (\%) \\
\hline $\begin{array}{l}\text { New Brunswick } \\
\text { Nova Scotia } \\
\text { Quebec } \\
\text { Ontario } \\
\text { Manitoba } \\
\text { Alberta } \\
\text { British Columbia } \\
\text { Yukon Territory }\end{array}$ & $\begin{array}{r}2 \\
8 \\
33 \\
1 \\
16 \\
16\end{array}$ & $\begin{array}{r}1 \\
\\
5 \\
25 \\
3 \\
10 \\
14\end{array}$ & $\begin{array}{r}2 \\
5 \\
25 \\
1 \\
29 \\
41\end{array}$ & $\begin{array}{r}1 \\
6 \\
19 \\
75 \\
2 \\
14 \\
40\end{array}$ & $\begin{array}{r}5 \\
14 \\
123 \\
2 \\
61 \\
23 \\
1\end{array}$ & $\begin{array}{rr}2 & (0 \cdot 3) \\
15 & (2 \cdot 4) \\
51 & (8 \cdot 2) \\
281 & (45 \cdot 1) \\
9 & (1 \cdot 4) \\
130(20 \cdot 9) \\
134(21 \cdot 5) \\
1 & (0 \cdot 2)\end{array}$ \\
\hline Total & $76^{*}$ & 58 & 103 & 157 & 229 & 623 \\
\hline
\end{tabular}

* 69 of these strains were characterised previously and were reported in previous publications. " Numbers are recorded according to year of receipt at the Laboratory Centre for Disease Control, Ottawa.
PLASMID ANALYSIS AND AUXOTYPING

We isolated and identified plasmid DNA as described by Dillon et al..$^{30}$ Auxotyping was completed using methods described by Hendry and Stewart ${ }^{31}$ and modified by Hendry. ${ }^{32}$

\section{SEROLOGICAL CLASSIFICATION}

Typing serum samples and reference strains were a gift from $S$ Bygdeman of the Karolinska Institute, Stockholm, Sweden. Serological classification of strains by coagglutination using monoclonal antibodies to protein 1 was performed as described by Tam et $a^{3{ }^{3}}$ and Bygdeman et al. ${ }^{34}$

\section{Results}

\section{INCIDENCE OF PPNG STRAINS}

As part of a national surveillance programme, PPNG strains isolated in Canada are submitted to this centre for biological and genetic identification and for clinical and epidemiological documentation. Table I shows the incidence of PPNG strains reported in 1976-

TABLE II Geographical origin of infections with penicillinase producing Neisseria gonorrhoeae (PPNG) strains in Canada

\begin{tabular}{|c|c|c|c|c|c|c|}
\hline \multirow[b]{2}{*}{$\begin{array}{l}\text { Origin of } \\
\text { infection* }\end{array}$} & \multicolumn{6}{|c|}{ No of PPNG strains isolated in: } \\
\hline & $1976-80$ & 1981 & 1982 & 1983 & 1984 & Total \\
\hline $\begin{array}{l}\text { Asia: } \\
\text { Phillipines } \\
\text { Thailand } \\
\text { Others }\end{array}$ & $\begin{array}{r}12 \\
10 \\
9\end{array}$ & $\begin{array}{r}3 \\
0 \\
12\end{array}$ & $\begin{array}{r}5 \\
11 \\
15\end{array}$ & $\begin{array}{r}3 \\
8 \\
14\end{array}$ & $\begin{array}{r}7 \\
7 \\
23\end{array}$ & $\begin{array}{l}30 \\
36 \\
73\end{array}$ \\
\hline Africa & 2 & 1 & 4 & 4 & 15 & 26 \\
\hline Europe & & & 1 & 2 & 3 & 6 \\
\hline South America & & & & 11 & 8 & 19 \\
\hline $\begin{array}{l}\text { Caribbean and } \\
\text { Central America }\end{array}$ & 5 & 3 & 5 & 14 & 26 & 53 \\
\hline $\begin{array}{l}\text { North America: } \\
\text { United States } \\
\text { Unknown } \\
\text { Canada }\end{array}$ & 6 & 1 & 4 & 3 & $\begin{array}{l}2 \\
1\end{array}$ & $\begin{array}{r}16 \\
1\end{array}$ \\
\hline $\begin{array}{l}\text { Foreign contact } \\
\text { Canadian origin }\end{array}$ & $\begin{array}{r}10 \\
6\end{array}$ & $\begin{array}{l}5 \\
7\end{array}$ & $\begin{array}{r}7 \\
24\end{array}$ & $\begin{array}{l}15 \\
45\end{array}$ & $\begin{array}{r}17 \\
101\end{array}$ & $\begin{array}{r}54 \\
183\end{array}$ \\
\hline $\begin{array}{l}\text { Geographical } \\
\text { origin unknown }\end{array}$ & 16 & 26 & 27 & 38 & 19 & 126 \\
\hline Total & 76 & 58 & 103 & 157 & 229 & 623 \\
\hline
\end{tabular}

Others in Asia: Korea (17), Taiwan (11), Hong Kong (10), India (3), Vietnam (2), Singapore (4), Japan (4), Indonesia (6), Israel (1), Malaysia (1), Saudi Arabia (2), Oman (1), not specified (11).

Africa: Uganda (1), Zambia (1), Cameroon (1), Ivory Coast (1) Nigeria (4), Ghana (5), Kenya (2), South Africa (2), Botswana (1), Mali (1), not specified (7).

Europe: Germany (2), Netherlands (1), Austria (1), Greece (1), not specified (1).

South America: Guyana (15), Brazil (3), not specified (1).

Central America and Caribbean: Ja maica (15) Mexico (6), Antigua (6), Barbados (5), Bahamas (4), Dominican Republic (2). Costa Rica (2), Virgin Islands (1), Martinique (1), Grenada (2), Trinidad \& Tobago (1), Panama (1), not specified (7). 
84. During 1984, the fourth consecutive year in which the number of infections caused by PPNG strains rose appreciably, the number of PPNG strains reported in Canada was $46 \%$ more than in the previous year. Most $(80.3 \%)$ of these strains were reported from the provinces of Ontario and Alberta, where local distinctive outbreaks had occurred. A PPNG strain was isolated in the Yukon Territories for the first time during 1984.

\section{GEOGRAPHICAL ORIGIN OF INFECTIONS WITH PPNG STRAINS}

Table II shows that in 1984 , for the first time since surveillance was started, the number of patients identifying a Canadian origin of infection was almost half of those for whom a geographical origin of infection could be ascertained. This increase was due to two endemic outbreaks; one (the "Toronto" outbreak) affected 20 patients, and the other (in the province of Alberta) affected 50. The strains isolated during these two outbreaks represented $31 \%$ of the total isolations during 1984 . In previous years, most infections had been contracted abroad $(62.2 \%(74 / 119$ with known origin) in 1983 and $68.4 \%(52 / 76)$ in 1982). Though the Far East continued to be the single area from which most PPNG strains were imported, the number of strains imported from the Caribbean areas and Africa in 1984 increased substantially. In addition, in 1983-4 PPNG strains were more commonly imported from South America, primarily Guyana.

\section{AGE AND SEX OF PATIENTS INFECTED WITH PPNG} STRAINS

Data about the age and sex of patients infected with PPNG strains (table III) indicate a ratio of men to women of 1.4:1 in 1984, which was down slightly from a ratio of $1 \cdot 6: 1$ in 1983. From 1976 to 1982 the ratio of men to women had been $2 \cdot 6: 1$ to $2 \cdot 3: 1$. In 1984 men aged 25 to 35 and women aged 20 to 24 showed the highest incidence of infection with PPNG strains. During 1983 and 1984 infections with PPNG strains were noted in five patients aged 15 and under, most of whom were young prostitutes.

PLASMID CONTENT, AUXOTYPE, AND RELATED CHARACTERISTICS OF PPNG STRAINS

We identified five distinct plasmid patterns in PPNG strains isolated in Canada (table IV). The first four patterns comprised the traditional Asian (4.5 megadalton) and African ( 3.2 megadalton) types either with (Asia+, Africa+) or without (Asia-, Africa $\left.^{-}\right)$the transfer ( 24.5 megadalton) plasmid. Most strains $(61.5 \%)$ were of the Asia t type, followed by Asia- (18.8\%), Africa- (10.6\%), and Africa+ (5.2\%) types. In 1984, analysis of an outbreak affecting 20 patients uncovered a new penicillinase encoding
TABLE III Age and sex of patients infected with penicillinase producing Neisseria gonorrhoeae (PPNG) strains in Canada.

\begin{tabular}{|c|c|c|c|c|c|c|c|}
\hline \multirow[b]{2}{*}{$\operatorname{Sex}$} & \multirow[b]{2}{*}{ Age (yrs) } & \multicolumn{6}{|c|}{ No of PPNG strains isolated in: } \\
\hline & & $1976-80$ & 1981 & 1982 & 1983 & 1984 & Total \\
\hline Men: & $\begin{array}{l}\leq 15 \\
16-19 \\
20-24 \\
25-34 \\
35-44 \\
\geq 45 \\
\text { Unknown }\end{array}$ & $\begin{array}{r}0 \\
2 \\
7 \\
22 \\
3 \\
0 \\
18\end{array}$ & $\begin{array}{l}0 \\
1 \\
3 \\
6 \\
4 \\
1 \\
8\end{array}$ & $\begin{array}{r}0 \\
0 \\
6 \\
16 \\
9 \\
1 \\
40\end{array}$ & $\begin{array}{r}1 \\
3 \\
21 \\
24 \\
15 \\
5 \\
25\end{array}$ & $\begin{array}{r}1 \\
16 \\
27 \\
40 \\
21 \\
4 \\
21\end{array}$ & $\begin{array}{r}2 \\
22 \\
64 \\
108 \\
52 \\
11 \\
112\end{array}$ \\
\hline Sub & total & 52 & 23 & 72 & 94 & 130 & 371 \\
\hline Wome & $\begin{array}{l}\text { n: } \\
\leq 15 \\
16-19 \\
20-24 \\
25-34 \\
35-44 \\
\geq 45 \\
\text { Unknown }\end{array}$ & $\begin{array}{l}0 \\
0 \\
8 \\
7 \\
3 \\
0 \\
2\end{array}$ & $\begin{array}{l}0 \\
0 \\
1 \\
4 \\
1 \\
1 \\
2\end{array}$ & $\begin{array}{r}0 \\
1 \\
7 \\
6 \\
1 \\
2 \\
14\end{array}$ & $\begin{array}{r}0 \\
9 \\
11 \\
13 \\
1 \\
3 \\
21\end{array}$ & $\begin{array}{r}3 \\
17 \\
41 \\
17 \\
7 \\
2 \\
7\end{array}$ & $\begin{array}{r}3 \\
27 \\
68 \\
47 \\
13 \\
8 \\
46\end{array}$ \\
\hline Sub & total & 20 & 9 & 31 & 58 & 94 & 212 \\
\hline Unknc & own & 4 & 26 & 0 & 5 & 5 & 40 \\
\hline Total & & 76 & 58 & 103 & 157 & 229 & 623 \\
\hline
\end{tabular}

plasmid of 3.05 megadaltons (a preliminary report on the molecular nature of this plasmid has been presented previously). ${ }^{18}$ We have named this the Toronto type plasmid. Strains of this type, which comprise $4 \%$ of all PPNG strains identified to date, also carried a transfer plasmid. About $65-73 \%$ of the PPNG strains isolated in Canada during a given year carried the 24.5 megadalton transfer plasmid. This plasmid was isolated from strains harbouring either the Asian type $(308 / 402 ; 76.6 \%)$ or the Toronto type (20/20) penicillinase encoding plasmids. Only $32.9 \%$ $(26 / 79)$ of strains with the African type plasmid also carried the transfer plasmid.

Auxanographic analysis of the isolates indicated that most PPNG strains were either wild type (nonrequiring) or required proline for growth. Strains that carried the 3.2 megadalton or the 3.05 megadalton penicillinase encoding plasmids were predominantly wild type ( $74.7 \%$ and $100 \%$, respectively). Fifty nine percent of the strains carrying the 4.5 megadalton penicillinase encoding plasmid required proline or proline and ornithine for growth. Strains with the auxotype that required proline and ornithine were associated with an outbreak affecting 50 patients during 1984. Several other auxotypes comprised only $2 \%$ of the PPNG strains identified.

Isolates were tested for inhibition of growth by phenylalanine. None of the isolates with the 3.05 megadalton penicillinase encoding plasmid and two of $192(1 \%)$ isolates with the Asian type plasmid were inhibited. By contrast $43.3 \%(29 / 67)$ of isolates with the African type plasmid were inhibited by phenylalanine. Of the 29 strains with the African type 
plasmid that were inhibited, $25(86.2 \%)$ were of the wild type auxotype and $72 \%$ of these strains $(18 / 25)$ were Africa :

Table $\mathrm{V}$ analyses the plasmid content and auxotype of PPNG strains and the geographical source of infection. Strains imported from Africa were of the Africa $\left(+\right.$ or $\left.^{-}\right)$and Asia ( + or $\left.{ }^{-}\right)$types and included non-requiring and proline requiring auxotypes. By contrast, only two strains of Asian origin were Africat, the rest being Asiat or Asia- Strains imported from South American, Central American, and Caribbean countries carried all varieties of the African and Asian plasmid combinations. PPNG strains imported from the United States of America into Canada were predominantly $(15 / 16)$ of the Asiat or Asia-type.

Serological analysis of patients infected in Toronto and Alberta indicated that distinct strains were implicated in each outbreak. Strains with the Toronto type (3.05 megadalton) plasmid were serologically typed as group WII/WIII serovar BACJK. The proline and ornithine requiring isolates associated with the Alberta outbreak were of the WI serotype, serovar AE. Other proline and ornithine requiring PPNG strains not associated with the outbreak were also serotype WI but had different serovars (data not shown).

\section{Discussion}

The results of the study published here show that the continued epidemiological and molecular surveillance of penicillinase producing strains of $N$ gonorrhoeae is essential to control their epidemic spread within a country, to monitor new varieties of $B$ lactamase encoding plasmids, and to distinguishing new host strains. During 1984 PPNG strains caused $0.5 \%$ of the 43880 cases of infectious gonorrhoea reported in Canada. ${ }^{35}$ This low incidence is typical of other countries, such as the United States of America, ${ }^{28} 36$ Nordic countries, ${ }^{2137}$ and the United Kingdom. ${ }^{38}$
Most infections with PPNG strains in these countries were due to strains imported from areas of endemic infection. ${ }^{20}{ }^{39}$ Compared with the 1970 s, the number of countries in which PPNG strains are endemic is increasing. In Holland in 1983 PPNG strains comprised $10 \%$ of gonococcal isolates, ${ }^{27}$ and in Amsterdam in 1984 this number had risen to $18 \%$ of all new infections. ${ }^{9}$ Countries in South East Asia have reported that as many as $40 \%$ of infections are caused by PPNG strains. ${ }^{416} 2440$ The increase of PPNG strains in West Africa, which mirrors the rapid dissemination of PPNG strains throughout Asia five years previously, presents a particularly alarming model for the epidemic spread of these strains. For example, in Kenya the first PPNG strains was detected in July 1981; by November 1982 PPNG strains caused $22 \%$ of cases of gonococcal urethritis in men and had spread to remote areas of the country. ${ }^{25}$ PPNG strains have been isolated from many other African countries, often in large numbers. ${ }^{41}$

The importation of PPNG strains into Canada, which has been primarily from areas where they are endemic such as South East Asia and parts of Africa (table II), reflects the changed incidence of PPNG strains in a particular area (for example more PPNG strains are now imported from Africa and areas of Asia other than Thailand and the Phillipines than in the early 1980s). In this regard, the appreciable level of importation from the Caribbean indicates a problem there, which might warrant increased surveillance.

The age distribution of women patients in Canada, with those aged 20 to 24 having the highest incidence, is similar to that reported in Britain. ${ }^{42}$ The high incidence in Canadian men aged 25 to 34 is in contrast to a British report where the highest incidence in men was in those aged 20 to 24 . The number of PPNG strains in patients aged under 15 in Canada was primarily attributed to young prostitutes. Prostitutes were implicated in the two local outbreaks in Canada in 1984. The role of prostitutes in contributing to the spread of PPNG strains has been referred to by many

TABLE IV Plasmid content and auxotype of 501 PPNG isolates

\begin{tabular}{|c|c|c|c|c|c|c|c|c|}
\hline \multirow[b]{2}{*}{ Plasmid pattern* } & \multicolumn{8}{|c|}{ Auxotype $\dagger$} \\
\hline & $N R$ & Pro $^{-}$ & $\mathrm{Orn}^{-}$ & Pro $^{-} \mathrm{Orn}^{-}$ & Pro $^{-} \mathrm{Hyx}^{-}$ & Meth & Pro $^{-}$Meth $^{-}$ & Total (\%) \\
\hline $\begin{array}{l}\text { Africa+ } \\
\text { Africa- } \\
\text { Asiat } \\
\text { Asia- } \\
\text { Toronto+ }\end{array}$ & $\begin{array}{r}18 \\
41 \\
154 \\
6 \\
20\end{array}$ & $\begin{array}{r}5 \\
8 \\
102 \\
84\end{array}$ & $\begin{array}{l}2 \\
1 \\
1\end{array}$ & $\begin{array}{r}2 \\
51\end{array}$ & 1 & 1 & 3 & $\begin{array}{r}26(5 \cdot 2) \\
53(10 \cdot 6) \\
308(61 \cdot 5) \\
94(18 \cdot 8) \\
20(3 \cdot 9)\end{array}$ \\
\hline Total (\%) & $239(47 \cdot 7)$ & $199(39 \cdot 7)$ & $4(0.8)$ & $53(10 \cdot 6)$ & $2(0 \cdot 4)$ & $1(0 \cdot 2)$ & $3(0.6)$ & 501 \\
\hline
\end{tabular}

* All strains harboured a 2.6 megadalton cryptic plasmid. In addition Africa types harboured a 3.2 megadalton plasmid whereas Asia types harboured a 4.5 megadalton plasmid, both with (+) or without (-) the 24.5 transfer plasmid. The Toronto+ type harboured a 3.05 megadalton plasmid in addition to the transfer plasmid.

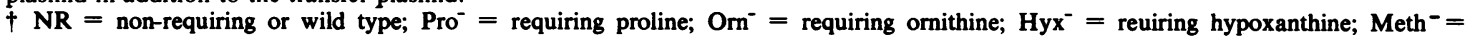
requiring methionine. 
other workers. 92539

The use of molecular, genetic, and serological techniques has been specially useful epidemiologically. Previous studies indicated that the range of gonococcal hosts of the African and Asian type $B$ lactamase encoding plasmids had been extended to include new combinations of auxotypes and plasmids. ${ }^{11-15}$ Furthermore, $\boldsymbol{\beta}$ lactamase encoding plasmids different in size from the African and Asian type plasmids have been identified. ${ }^{17-19}$ In the report published here unusual (proline and ornithine requiring) PPNG auxotypes and new plasmid combinations (Toronto plasmid) contributed to two unique outbreaks in Canada during 1984. Strains related to each of the outbreaks were unequivocally identified only by using a combination of molecular and biochemical techniques. Restriction endonuclease mapping of the Toronto plasmid indicated that it was a deletion derivative of the Asian type penicillinase encoding plasmid. ${ }^{1718}$ Recently, workers in the Netherlands have isolated a 2.9 megadalton plasmid from two strains that seem to be similar to the Toronto type plasmid. ${ }^{19}$ No definitive epidemiological link has been established between the Toronto outbreak and infection in other areas.

Most PPNG strains analysed in the study published here carried an Asian type plasmid. Most (54.3\%) of the strains of the Asia-type were imported from Asia and only $27 \cdot 2 \%$ had a Canadian origin. By contrast, strains of the Asia+ type were predominantly (51.1\%) of Canadian origin with only $32.3 \%$ of Asian origin. Similarly, $63.6 \%$ of the strains of the Africat type were "Canadian" as opposed to only $38.8 \%$ of the Africa ${ }^{-}$strains. Most strains with the African type plasmid were imported from areas other than Africa, including Asia. In view of the appreciable numbers of strains of the Asiat or Africat types in which the origin of infection was Canada, there is possibly an unreported and undetected reservoir of PPNG strains. It is interesting to note, in contrast to Canadian data, that most PPNG strains isolated in the Netherlands have African type plasmids. ${ }^{927}$ Nevertheless, the distinction between African and Asian strains based solely on plasmid analysis has, for some time, proved to be ineffective as a method of differentiation between strains, as these plasmid types are seen in all geographical areas. ${ }^{22} 42$

The correlation between auxotype, plasmid carriage, and inhibition by phenylalanine observed in this and other reports, ${ }^{41043}$ as Buisson et al state, ${ }^{44}$ continues to be an intriguing but unexplained phenomenon. The associations between proline requiring auxotypes and carriage of the Asian type plasmid and between non-requiring auxotypes and carriage of the African type plasmid were observed in the analysis of some of the first PPNG strains isolated, ${ }^{6}$ and continue to be observed in more recent studies. ${ }^{9} 1044$ Similarly, strains with the African type plasmid, which are predominantly wild type, are inhibited by phenylalanine whereas strains with the

TABLE V Analysis of geographical origin of infection and plasmid content and auxotype of penicillinase producing Neisseria gonorrhoeae (PPNG) strains

\begin{tabular}{|c|c|c|c|c|c|c|c|c|c|}
\hline \multirow[b]{2}{*}{ Plasmid pattern* } & \multirow[b]{2}{*}{ Auxotype } & \multicolumn{8}{|c|}{ Geographical source of infection* } \\
\hline & & Europe & Africa & Asia & $S$ America & $\begin{array}{l}\text { C Americal } \\
\text { Carribean }\end{array}$ & Canada & $U S A$ & Total \\
\hline Africat & $\begin{array}{l}\text { NR } \\
\text { Pro- } \\
\text { Orn- } \\
\text { Pro=hyx- }\end{array}$ & & 1 & $\begin{array}{l}1 \\
1\end{array}$ & $\begin{array}{l}1 \\
1\end{array}$ & $\begin{array}{l}2 \\
1\end{array}$ & $\begin{array}{r}11 \\
2 \\
1\end{array}$ & & $\begin{array}{r}15 \\
4 \\
2 \\
1\end{array}$ \\
\hline Africa- & $\begin{array}{l}\text { NR } \\
\text { Pro- } \\
\text { Orn- } \\
\text { Pro-orn- } \\
\text { Meth- }\end{array}$ & $\begin{array}{l}2 \\
1\end{array}$ & $\begin{array}{l}6 \\
4 \\
\\
1\end{array}$ & & 2 & $\begin{array}{r}11 \\
1 \\
1\end{array}$ & $\begin{array}{r}16 \\
2 \\
1\end{array}$ & 1 & $\begin{array}{r}37 \\
8 \\
1 \\
2 \\
1\end{array}$ \\
\hline Asiat & $\begin{array}{l}\text { NR } \\
\text { Pro- } \\
\text { Orn- } \\
\text { Pro-orn- }\end{array}$ & 1 & $\begin{array}{l}4 \\
4\end{array}$ & $\begin{array}{r}49 \\
33 \\
1 \\
3\end{array}$ & 2 & $\begin{array}{r}7 \\
13\end{array}$ & $\begin{array}{l}63 \\
27 \\
\\
46\end{array}$ & $\begin{array}{l}7 \\
5 \\
1\end{array}$ & $\begin{array}{r}131 \\
84 \\
1 \\
50\end{array}$ \\
\hline Asia- & $\begin{array}{l}\text { NR } \\
\text { Pro- } \\
\text { Pro-hyx- } \\
\text { Pro-meth- }\end{array}$ & & 3 & $\begin{array}{r}4 \\
38 \\
2\end{array}$ & 2 & $\begin{array}{l}7 \\
1\end{array}$ & $\begin{array}{r}1 \\
20 \\
1\end{array}$ & 2 & $\begin{array}{r}5 \\
72 \\
1 \\
3\end{array}$ \\
\hline Toronto+ & NR & & & & & & 18 & & 18 \\
\hline Total (\%) & & $4(0.9)$ & $23(5 \cdot 3)$ & $132(30 \cdot 3)$ & $8(1 \cdot 8)$ & $44(10 \cdot 1)$ & $209(47 \cdot 9)$ & $16(3 \cdot 7)$ & 436 \\
\hline
\end{tabular}

* See table IV for definitions of plasmid patterns and auxotypes. No data regarding origin of infection of 65 strains analysed, 55 of which carried Asian type plasmids, eight carried African typeplasmids, and the remaining two strains were Toronto type. See table 2 for list of countries within geographical areas. 
Asian type plasmid are not inhibited. ${ }^{91443}$ In the report published here, however, under half the strains with the African type plasmid were inhibited by phenylalanine compared with over $90 \%$ in studies by Ansink-Schipper et al. ${ }^{914}$ We also found that a few strains with the Asian type plasmid were inhibited by phenylalanine, in contrast to Dutch reports in which none of the strains were inhibited. These differences might be explained if the African type strains in the Dutch studies were in fact derived from a limited number of strains circulating in the population. Most of the African type strains in Canada were imported from diverse areas and were unrelated.

The surveillance of PPNG strains in Canada using molecular techniques is part of a national control strategy undertaken in cooperation with provincial health authorities. These tests are undertaken in addition to the screening of all gonococci for $B$ lactamase production, the use of spectinomycin to treat high risk patients, and rapid contact tracing. A combination of these measures has been effective in identifying PPNG strains in this and other countries and in rapidly pinpointing and controlling local outbreaks. ${ }^{172} 29$ The combination of these measures has, we hope, contributed appreciably to the continued low incidence of PPNG strains in Canada.

We thank the provincial public health laboratories, other laboratory centres, and provincial epidemiologists throughout Canada for sending us PPNG strains and for supplying clinical and epidemiological data about patients.

\section{References}

1. Ashford WA, Golash RG, Hemming VG. Penicillinaseproducing Neisseria gonorrhoeae. Lancet 1976;ii:657-8.

2. Ashford WA, Lucas RN, Miller MB, Chin J, Marek WJ, Acree KH. Penicillinase-producing Neisseria gonorrhoeae. MMWR 1976;25:261.

3. Percival A, Rowlands J, Corkill JE. Penicillinase-producing gonococci in Liverpool. Lancet 1976;ii:1379-82.

4. Perine PL, Morton RS, Piot P, et al. Epidemiology and treatment of penicillinase-producing Neisseria gonorrhoeae. Sex Transm Dis 1979;6(suppl):152-8.

5. Riou JY, Courvalin P. Neisseria gonorrhoeae plasmids: theoretical study and practical consequences. WHO/VDT/RES/GON/85:1985;146:1-24.

6. Perine PL, Thornsberry C, Schalla W, et al. Evidence for two distinct types of penicillinase-producing Neisseria gonorrhoeae. Lancet 1977;ii:993-5.

7. Elwell LP, Roberts M, Mayer LW, Falkow S. Plasmid-mediated beta-lactamase production in Neisseria gonorrhoeae. Antimicrob Agents Chemother 1977;11:528-33.

8. Dillon JR, Duck P, Thomas DY. Molecular and phenotypic characterization of penicillinase-producing Neisseria gonorrhoeae from Canadiàn sources. Antimicrob Agents Chemother 1981;19:952-7.

9. Ansink-Schipper MC, Huikeshoven MH, Woudstra RK, et al. Epidemiology of PPNG infections in Amsterdam: analysis by auxanographic typing and plasmid characterisation. British Journal of Venereal Diseases 1984;60:23-8.

10. Dillon JR, Pauzé $M$. Introductory address: resistance to antimicrobial agents. What next for Neisseria gonorrhoeae? Sex Transm Dis 1984;ii(suppl):353-9.

11. Dillon JR, Pauzé M. Appearance in Canada of Neisseria gonorrhoeae strains with a $3 \cdot 2$ megadalton penicillinaseproducing plasmid and a 24.5 megadalton transfer plasmid. Lancet 1981;II;700.
12. Embden JDA van, Klingeren $B$ van, Dessens-Kroon $M$, Wijngaarden $L J$ van. Emergence in the Netherlands of penicillinase-producing gonococci carrying "Africa" plasmid in combination with transfer plasmid. Lancet 1981;i:938.

13. Johnston NA, Kolator B. Emergence in Britain of betalactamase-producing gonococci with new plasmid combination. Lancet 1982;i:445-6.

14. Ansink-Schipper MC, Embden JDA van, Klingeren B van, Woudstra R. Further spread of plasmids among different auxotypes of penicillinase-producing gonococci. Lancet 1982;i:445.

15. Jephcott AE, Eggleston SI, Copley C. Further evidence of dissemination of ability to produce penicillinase amongst gonococci. Lancet 1982;i:1467-8.

16. Odugbemi TO, Whittington WL, DeWitt W, et al. Epidemiological characterisation of Neisseria gonorrhoeae isolates from the Far East. British Journal of Venereal Diseases 1983:59:285-8.

17. Yeung K-H, Dillon JR, Pauzé M, Wallace E. Outbreak of PPNG caused by a novel $4.9 \mathrm{kd}$ penicillinase-producing plasmid (Toronto-type) related to the Asian-type plasmid. J Infect Dis (in press).

18. Yeung $\mathrm{K}-\mathrm{H}$, Dillon JR. In vitro transcription/translation products and molecular characterisation of naturally occurring and in vitro deletion derivatives of the $7.2 \mathrm{kd}$ plasmid of Neisseria gonorrhoeae. In: Schoolnik GK, ed. The Pathogenic neisseriae. Proceedings of the fourth international symposium. Washington DC: American Society for Microbiology, 1985:209-15.

19. Embden JDA van, Dessens-Kroon M, Klingeren B van. A new B lactamase plasmid in Neisseria gonorrhoeae. J Antimicrob Chemother 1985;15:247-58.

20. Handsfield HH, Sandström EG, Knapp JS, et al. Epidemiology of penicillinase-producing Neisseria gonorrhoeae infections. Analysis by auxotyping and serogrouping. $N$ Engl J Med 1982;306:950-4.

21. Bygdeman S, Kallings I, Danielsson D. Serological grouping and auxotyping for epidemiological study of B-lactamaseproducing Neisseria gonorrhoeae strains isolated in Sweden. Acta Derm Venereol (Stockh) 1981;61:329-34.

22. Odugbemi TO, Brown ST, Biddle J, et al. Plasmid profile, serogrouping, and auxotyping of Neisseria gonorrhoeae isolates from Africa. British Journal of Venereal Diseases 1983;59:41-3.

23. Falk ES, Danielsson D, Bjorvator B, et al. Phenotypic and genotypic characterization of penicillinase-producing strains of Neisseria gonorrhoeae. Acta Pathol Microbiol Immunol Scand $[B]$ 1985;93:91-7.

24. Rajan VS, Thirumoorthy T, Tan NJ. Epidemiology of penicillinase-producing Neisseria gonorrhoeae in Singapore. British Journal of Venereal Diseases 1981;57:158-6i.

25. Plummer F, Nsanze H, D'Costa L, Slaney L, Ronald A. Molecular epidemiology of penicillinase-producing Neisseria gonorrhoeae (PPNG) in Kenya. In: Nsanze H, Widy-Wirski RH, Ellison RH eds. Proceedings of the third African regional conference on sexually transmitted diseases. Basle, Switzerland: Ciba Geigy Ltd, 1983;27-8.

26. Widy-Wirski R, Meheus A, Lala B, Piot P, D'Costa J Thiamphenicol in treatment of genital gonorrhoeae in Central African Republic. in: Nsanze H., Widy-Wirski RH, Ellison RH eds. Proceedings of the third African regional conference on sexually transmitted diseases. Basle, Switzerland: Ciba Geigy Ltd, 1983:69-71.

27. Klingeren $B$ van, Wijngaarden $L J$ van, Dessens-Kroon $M$, Embden JDA van. Penicillinase-producing gonococci in the Netherlands in 1981. J Antimicrob Chemother 1983;11:15-20.

28. Jaffe HW, Biddle JW, Johnson SR. Wiesner PJ. Infections due to penicillinase-producing Neisseria gonorrhoeae in the United States 1976-1980. J Infect Dis 1981;144:191-7.

29. Dillon JR. Laboratory methods for Neisseria gonorrhoeae (MIC, auxotype, screening for PPNG). Ottawa, Canada: National Health and Welfare. 1983 (Catalogue No H47-58/1983E).

30. Dillon JR, Bezanson GS, Yeung K-H. Basic techniques. In: Dillon JR, Nasim A, Nestmann ER, eds. Recombinant DNA methodology. New York: John Wiley and Sons, 1985:1-126.

31. Hendry AT, Stewart IO. Auxanographic grouping and typing of Neisseria gonorrhoeae. Can J Microbiol 1979:25:512-21.

32. Hendry AT. Growth responses of Neisseria gonorrhoeae auxotypes to required amino acids and bases in liquid medium. Can J Microbiol 1983;29:1309-13. 
33. Tam MR, Buchanan TM, Sandström EG, et al. Serological classification of Neisseria gonorrhoeae with monoclonal antibodies. Infect Immun 1982;36:1042-53.

34. Bygdeman S, Danielsson D, Sandström E. Gonococcal W serogroups in Scandinavia. A study with polyclonal and monoclonal antibodies. Acta Pathol Microbiol Immunol Scand [B] 1983;91:239-305.

35. Anonymous Notifiable diseases summary. Canada Diseases Weekly Report 1985;136:11-31:

36. Anonymous. Annual summary 1983. MMWR 1984;32:22-5.

37. Lind I. Activities of WHO collaborating centre for reference and research in gonococci, Copenhagen, for the year 1983 WHO/VDT/RES/GON/84 1984;144:1-15.

38. Adler MW, McCutchan JA. Survey of cases of gonorrhoea caused by penicillinase producing Neisseria gonorrhoeae in the United Kingdom. Genitourin Med 1985;61:36-8.

39. Arya OP, Rees E, Turner GC, et al. Epidemiology of penicillinase-producing Neisseria gonorrhoeae in Liverpoo from 1977 to 1982 . $J$ Infect 1984;8:70-83.
40. Brown S, Warnnissorn T, Biddle J, Panikabutra A, Traisupa K. Antimicrobial resistance of Neisseria gonorrhoeae in Bangkok. Is single-drug treatment passé. Lancet 1982;ii:1366-8.

41. Joshi RH, Lawande RV. Sensitivity pattern and beta-lactamase screening of Neisseria gonorrhoeae strains isolated in Zaria, Northern Nigeria. Trop Geogr Med 1985;37:74-6.

42. Public Health Laboratory Service Communicable Disease Centre and Communicable Diseases (Scotland) Unit. Penicillinase-producing gonococci in Britain, 1983. Br Med J 1984;288:1746.

43. Hendry AT, Dillon JR. Growth inhibition of Neisseria gonorrhoeae isolates by L-phenylalanine and its analogues in defined media. Can J Microbiol 1984;30:1319-25.

44. Buisson Y, Riou JY, Labidi A, Arborio M, Guibourdenche M. A propos des gonocoques producteurs de bêtalactamase isolés à Dakar. Sensibilité à divers antibiotiques, auxotype et contenu plasmidique. Pathol Biol 1985;33:550-3. 